Pediat. Res. 3: 441-447 (1969)

Brain

galactose

growth retardation newborn

pregnancy

\title{
Effect of Galactose Toxicity on Growth of the Rat Fetus and Brain
}

\author{
J.C. HAWORTH ${ }^{[20]}$, J.D. Ford and M.K.YOUNOSZAI \\ The Research Foundation of the Winnipeg Children's Hospital and the Department of Paediatrics, \\ University of Manitoba, Winnipeg, Manitoba, Canada
}

\section{Extract}

In pregnant albino rats fed a diet containing $40 \%$ galactose, sugar crossed the placenta and was found in the blood, urine, and amniotic fluid of the fetuses. Galactose-1-phosphate was also found in fetal brain tissue.

The fetus of galactose-fed rats weighed 5 to $12 \%$ less than the fetus of control rats fed a diet of similar composition, but containing no galactose. Growth retardation was reversible. Fetuses of rats fed the galactose diet during the first half of pregnancy were less retarded than were those of rats fed galactose throughout pregnancy or during the second half of pregnancy only. Body weight of animals at 10 weeks of age did not differ significantly from that of control animals. In the galactosemic fetus, the reduction in brain weight was approximately equal to that in body weight.

In galactosemic fetuses, the content of DNA in brain was less than that in control animals, indicating a reduction in cell number. In a group of preterm fetuses 18 days of gestation, total protein content in brain was also reduced when compared with that of controls, suggesting a reduction in cell size. Brains of galactosemic fetuses at term, however, contained normal amounts of protein. Offsprings of galactose-fed rats examined at three and ten weeks of age had smaller brains than offsprings of control animals, but total DNA content was normal, indicating normal cell number.

These findings indicate that galactose toxicity is exhibited in the fetal rat by retardation in body growth. Brain growth is also affected, apparently as a result of interference with cell replication and, perhaps to some extent, with cell growth.

\section{Speculation}

Although it is as yet unknown whether exposure of human fetuses to high concentrations of galactose affects growth of the brain, clinical observations suggest that it may do so. Mental performance of galactosemic children is at times subnormal despite early treatment with a galactose-free diet. Evidence is accumulating which suggests that mothers known to be heterozygous for the galactosemia gene should be treated with a diet low in lactose during pregnancy. 
Introduction

Symptoms of congenital galactosemia usually become apparent a few days after milk feedings are begun. There is, however, variability in the clinical manifestations of this disorder. The following observations suggest that, in some cases, the disease process begins before birth. Elevated levels of galactose-1-phosphate have been demonstrated in erythrocytes of the cord blood at the time of birth [11]. Cataracts and hepatic cirrhosis, when present at birth, may not regress after institution of a lactose-free diet [6]. The birth weight of galactosemic infants may average $0.3 \mathrm{~kg}$ less than that of their unaffected siblings [6]. Subsequent mental performance may be subnormal even in those patients for whom a treatment with a galactose-free diet is initiated early in life $[4,6]$. Galactose of maternal origin may be transmitted to the fetus in quantity sufficiently high to have an adverse effect upon the fetus in utero. Women who are heterozygous for the galactosemia gene, although clinically asymptomatic, are known to have impaired galactose tolerance, and it has been recommended that they avoid milk products during pregnancy [15].

In rats fed high concentrations of galactose during pregnancy, placental transfer of sugar has been demonstrated, and fetal growth retardation, cataracts, and lesions of fetal liver and kidney have been described $[1,12,13,14]$. The effect of galactose toxicity upon the developing brain in the rat fetus is as yet unreported.

The present study examines fetal growth retardation resulting from galactose toxicity in the rat with particular reference to cell number and cell size in the fetal brain.
Materials and Methods

Sperm-positive female Holtzman albino rats were used in all experiments. The time of mating was known to within eight hours: For each experiment, rats were divided into two groups of approximately equal size.

The galactose-fed group was fed a diet [17] of the following composition: casein $27 \%$, vegetable oil $10 \%$, USP salt mix XIV $4 \%$, starch $19 \%$, galactose $40 \%$, and vitamin supplements. In most of the experiments, the control group was fed an identical diet, with the exception that galactose was replaced by glucose. In a few experiments, control rats received standard rat chow. Since the offspring of rats fed these two control diets (CD) were almost identical in size, results of the experiments were combined. All mother rats were weighed at the beginning of each experiment, and an attempt was made to equalize the weights in both the control and the galactose-fed groups.

In a number of different experiments, variations were made in the time during which the galactose diet (GD) was fed and in the age of the offspring when examined (table I). Fetuses of rats fed GD during the latter half of pregnancy were examined on the 18th gestational day (preterm fetuses). Fetuses of other rats fed GD a) throughout pregnancy, b) during the second half of pregnancy only, and c) during the first half of pregnancy only were examined on the 22 nd gestational day (term fetuses). Offspring from other groups of rats were born normally, left with their mothers, and subsequently examined at three and ten weeks of age (follow-up groups). Dams of the latter group were fed GD during lactation.

In each experiment, food and water intake and urine excretion of several rats were measured during three-

Table I. Details of the experimental groups

\begin{tabular}{|c|c|c|c|c|c|}
\hline \multirow[t]{2}{*}{ Group } & \multicolumn{2}{|c|}{ No. of mother rats } & \multicolumn{2}{|c|}{ No. of young } & \multirow[b]{2}{*}{ Duration of galactose diet } \\
\hline & Gontrol & $\begin{array}{c}\text { Galactose } \\
\text { fed }\end{array}$ & Control & $\begin{array}{c}\text { Galactose } \\
\text { fed }\end{array}$ & \\
\hline \multicolumn{6}{|l|}{ Preterm fetuses } \\
\hline 18 gestational days & 8 & 7 & 54 & 45 & Gestational days $11-18$ \\
\hline \multicolumn{6}{|l|}{ Term fetuses } \\
\hline 22 gestational days a. & 4 & 4 & 40 & 36 & Gestational days $2-22$ \\
\hline 22 gestational days $b$. & 5 & 5 & 24 & 24 & Gestational days $11-22$ \\
\hline 22 gestational days $c$. & 6 & 6 & 57 & 50 & Gestational days $2-11$ \\
\hline Three-week old & 9 & 7 & 32 & 27 & Gestational day $11-21$ st day postpartum \\
\hline \multirow[t]{2}{*}{ 10-week old } & 18 & $9 \mathrm{M}$ & ale 11 & 10 & Gestational day $11-21$ st day postpartum \\
\hline & \multicolumn{3}{|c|}{ Female 12} & 10 & \\
\hline
\end{tabular}


day periods. Samples of urine were collected for determination of sugar content. Fetuses were obtained by cesarean section, immediately weighed, and then decapitated. Offsprings in the follow-up groups were killed by chloroform. Brains were removed immediately, weighed, frozen rapidly, and stored at $-20^{\circ}$ until chemical analyses were performed. Blood, amniotic fluid, and bladder urine were obtained from some of the fetuses for sugar analyses.

Galactose-1-phosphate was assayed by the semiquantitative method of Schwarz [10], and deoxyribonucleic acid (DNA) by the method of BuRTon [2] following preliminary fat extraction [5]. Protein (total nitrogen $\times 6.25$ ) was measured by the Kjeldahl method, and water, by drying the tissues to a constant weight. Galactose concentrations in blood, amniotic fluid, and urine were determined from the difference between total sugar [8] and glucose content [9]. Galactose-1-phosphate analyses of fetal organs were performed on tissues pooled for each litter. Determinations of DNA and protein content were performed on individual organs.

\section{Results}

Rats fed GD showed slightly greater increases in body weight (after removal of the fetuses and placentas) from the 2nd to 22nd day of gestation, consumed more food and water, and excreted more urine, when compared with rats fed CD (table II). Urinary sugar in galactosefed rats was identified as galactose. When the calculated caloric value of the galactose lost in urine was subtracted from the gross caloric intake, the net intake of calories in both the control and galactose-fed rats was approximately equal. There were no differences between the two groups in litter size, in sex ratio, or in the incidence of gross malformations, abortions, or stillbirths.

In fig. 1, body and brain weights of offspring of the galactose-fed rats are expressed as percentages of the weights of the corresponding control rats. Retardation of fetal body weight was greatest in the preterm fetuses, less in the term fetuses of rats fed GD throughout pregnancy, and least in the term fetuses of rats fed GD during the second half of pregnancy. Weights of the term fetuses of rats fed GD during the first half of pregnancy did not differ significantly from weights of controls. In the follow-up groups, significant reduction in body weight occurred only in the three-week-old group. Brain weights were decreased significantly in the offspring of all groups of galactose-fed rats and again, the most marked decrease was in the preterm fetuses.

Samples of amniotic fluid, blood, and urine from preterm and term fetuses of rats that received galactose during the second half of pregnancy showed average galactose concentrations of 300,180 , and $500 \mathrm{mg} / 100$ $\mathrm{ml}$, respectively. Concentrations of glucose in blood were in the normal range of $80 \mathrm{mg} / 100 \mathrm{ml}$. No galactose was detected in blood or urine of the three-week-old animals.

Chemical Composition of the Brain (table III)

Galactose-1-phosphate: pooled brains were analyzed from each of five litters of control and galactosemic preterm fetuses and from five litters of term fetuses of rats fed galactose during the second half of pregnancy. In the galactose-fed groups, galactose-1-phosphate was detected, except in one litter of preterm fetuses.

Table II. Effects of galactose diet on nutrition ${ }^{1}$

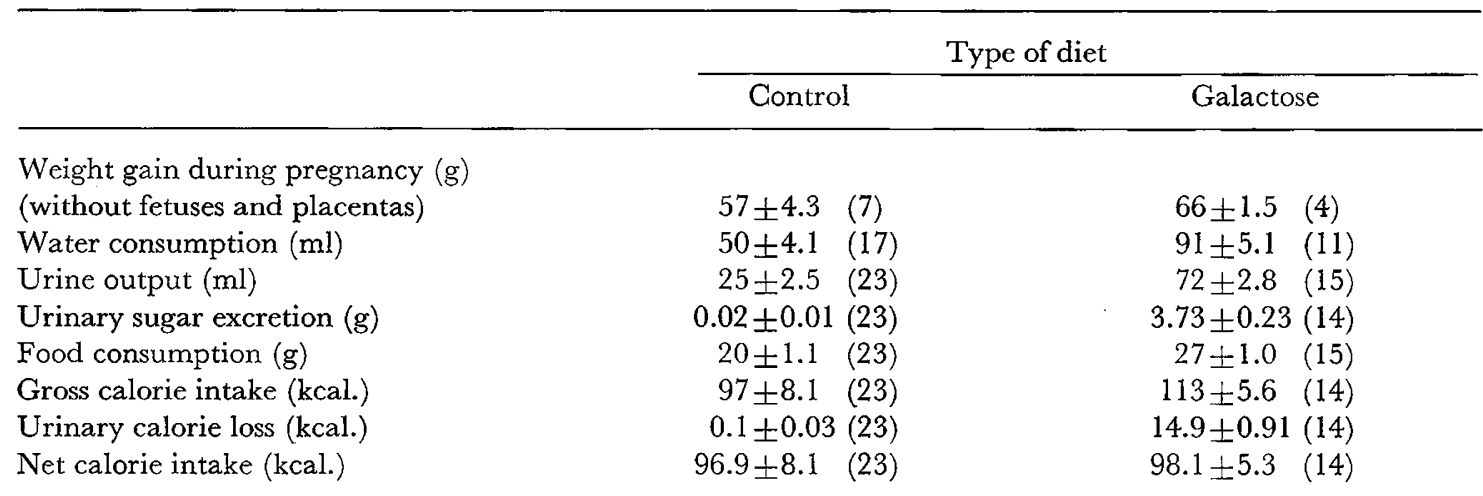

1 Values recorded are mean \pm standard error of the mean on a daily basis, except for weight gain. Figures in parentheses indicate number of observations. 
None was detected in the three-week-old animals or in the controls.

Water: no difference was detected in the water content of brains of offspring of the galactose-fed rats when compared with that of the corresponding controls.

DNA: brains of group (a) term galactosemic fetuses and of the three-week-old animals contained significantly more DNA (percent wet weight) and those of the group (c) term fetuses significantly less DNA, when compared with the content in brains of the respective controls. Total DNA content per brain was significantly less in the preterm and term galactosemic fetuses when compared with that in the respective controls. In the follow-up groups, DNA content per brain was not significantly different from that of controls.

Protein: there were no significant differences in the percentages of protein content in the brains of control and galactose-fed groups. Total protein content per brain in the galactosemic preterm fetuses, however, was significantly less than that in controls, although only six brains were available for analysis.

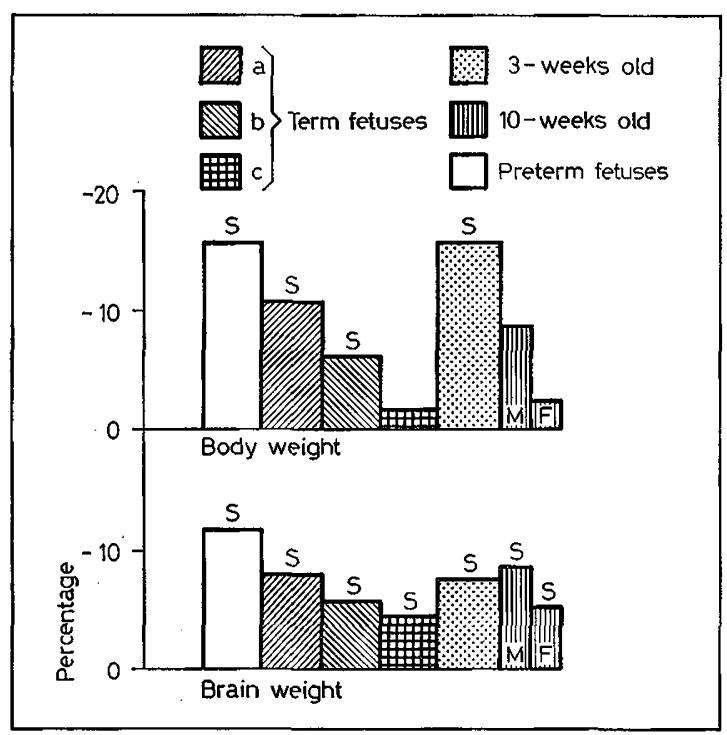

Fig. 1. Body and brain weights in galactosemic rats expressed as percent deviation from corresponding controls. An upright bar indicates that the measurement in the galactosemic animals was decreased compared with that in the control. The various groups of animals are defined in table I. Figures for male (M) and female (F) 10-week-old animals are shown separately. ' $S$ ' above the bars indicates that the mean measurement in the galactosemic animals differed significantly from that of the corresponding control $(\mathrm{p}$ $<0.05)$.

\section{Discussion}

In the present study, the high concentrations of galactose found in fetal blood, urine, and amniotic fluid and the accumulation of glactose-1-phosphate in the fetal brain confirm the observation that galactose crosses the placenta $[12,14]$.

Offspring of rats fed GD showed growth retardation at birth, thus confirming the findings of SPATz and SEGAL [13]. It should be noted that rats fed GD were not also malnourished, since growth retardation in the rat fetus can be produced readily by reduction of maternal food intake, fetal weight at term showing a direct correlation with food intake of the mother $[3,7,16]$. Although the galactose-fed dams had considerable galactosuria and polyuria, these animals remained in good health and appeared to compensate for the galactosuria by eating more. Weight quin was slightly greater during pregnancy, and net caloric intake was similar to that of control rats (table II). Urinary galactitol, however, was not measured, and a proportion of the ingested galactose that may have been excreted in this form was thus not considered. Probably, growth retardation was a direct result of the exposure of the fetuses to high concentrations of galactose during gestation. Reduction in body weight, however, did not appear to be permanent. 'Catch up' growth apparently occurred when the young were removed from the effects of galactose, since the 10-week-old animals were not significantly smaller than controls.

DNA concentration in brain was difficult to evaluate, since differences between that in brains of galactosemic and control fetuses were not consistent from one group to another. The significantly smaller amount of DNA per brain in the galactosemic fetuses indicated that these brains contained a smaller number of cells compared with the number of cells in the respective control brains. Brains of the galactosemic preterm fetuses also contained less total protein. This fact, together with a slightly lower protein/DNA ratio, which (assuming all the protein is intracellular) gives a measure of the amount of protein per cell, suggests that these brains may also have contained smaller cells compared with those in the brains of controls. Protein/ DNA ratios in the brains of term galactosemic fetuses, however, were similar to those in the brains of controls, suggesting normal cell size. Total DNA content in brains of the 3- and the 10-week-old follow-up groups did not differ significantly from that in brains of controls, indicating a normal cell number. These results suggest that galactose toxicity in the rat fetus interferes with cell replication and cell growth in the developing brain. This effect, however, appears to be partially reversible, since brains of the term fetuses showed less growth retardation than those of preterm fetuses. 
Table III. Fetal body and brain weight and chemical composition of brains of control and galactosemic animals ${ }^{\mathbf{1}}$

\begin{tabular}{|c|c|c|c|c|c|c|c|c|c|c|}
\hline \multirow{2}{*}{\multicolumn{2}{|c|}{ Group }} & \multirow[t]{2}{*}{ Diet $^{2}$} & \multirow{2}{*}{$\begin{array}{c}\text { Body weight } \\
\text { (g) }\end{array}$} & \multirow{2}{*}{$\begin{array}{l}\text { Brain weight } \\
\text { (mg) }\end{array}$} & \multirow[t]{2}{*}{ Water $\%$} & \multicolumn{2}{|c|}{ DNA } & \multicolumn{2}{|c|}{ Protein } & \multirow{2}{*}{$\begin{array}{c}\text { Protein/ } \\
\text { DNA }\end{array}$} \\
\hline & & & & & & $\%$ wet weight & $\mathrm{mg} /$ brain & $\%$ wet weight & $\mathrm{mg} / \mathrm{brain}$ & \\
\hline \multirow{2}{*}{\multicolumn{2}{|c|}{ Preterm fetuses }} & $\mathrm{C}$ & $\begin{array}{c}1.48 \pm 0.024 \\
(54)\end{array}$ & $\begin{array}{c}102 \pm 1.3 \\
(54)\end{array}$ & $\begin{array}{l}87.4 \pm 0.13 \\
(10)\end{array}$ & $\begin{array}{c}0.580 \pm 0.0134 \\
(15)\end{array}$ & $\begin{array}{c}0.629 \pm 0.0100 \\
(15)\end{array}$ & $\begin{array}{l}8.9 \pm 0.22 \\
(10)\end{array}$ & $\begin{array}{l}9.5 \pm 0.24 \\
(10)\end{array}$ & 15.1 \\
\hline & & G & $\begin{array}{c}1.25 * * * \pm 0.024 \\
(45)\end{array}$ & $\begin{array}{c}90 * * * \pm 1.1 \\
(45)\end{array}$ & $\begin{array}{c}86.9 \pm 0.22 \\
(6)\end{array}$ & $\begin{array}{c}0.575 \pm 0.0150 \\
(10)\end{array}$ & $\begin{array}{c}0.551 * * \pm 0.0197 \\
(10)\end{array}$ & $\begin{array}{c}8.3 \pm 0.30 \\
(6)\end{array}$ & $\begin{array}{c}7.4^{*} \pm 0.42 \\
(6)\end{array}$ & 13.4 \\
\hline \multirow[t]{6}{*}{ Term fetuses } & a) & G & $\begin{array}{c}6.88 \pm 0.064 \\
(40)\end{array}$ & $\begin{array}{c}256 \pm 4.0 \\
(37)\end{array}$ & $\begin{array}{c}87.7 \pm 0.33 \\
(10)\end{array}$ & $\begin{array}{c}0.305 \pm 0.0030 \\
(10)\end{array}$ & $\begin{array}{c}0.815 \pm 0.0122 \\
(10)\end{array}$ & $\begin{array}{l}8.8 \pm 0.31 \\
(10)\end{array}$ & $\begin{array}{c}22.6 \pm 1.13 \\
(10)\end{array}$ & 27.7 \\
\hline & & $\mathrm{G}$ & $\begin{array}{c}6.16 * * * \pm 0.051 \\
(36)\end{array}$ & $\begin{array}{c}235 * * * \pm 2.6 \\
(33)\end{array}$ & $\begin{array}{c}87.6 \pm 0.29 \\
(10)\end{array}$ & $\begin{array}{c}0.317 * \pm 0.0030 \\
(10)\end{array}$ & $\begin{array}{c}0.763 * \pm 0.0174 \\
(10)\end{array}$ & $\begin{array}{l}8.9 \pm 0.29 \\
(10)\end{array}$ & $\begin{array}{c}21.1 \pm 0.82 \\
(10)\end{array}$ & 27.7 \\
\hline & b) & $\mathrm{G}$ & $\begin{array}{c}6.50 \pm 0.077 \\
(24)\end{array}$ & $\begin{array}{c}245 \pm 2.0 \\
(24)\end{array}$ & - & - & - & - & - & - \\
\hline & & $\mathrm{G}$ & $\begin{array}{c}6.10 * * * \pm 0.072 \\
(24)\end{array}$ & $231 * * * \pm 1.9$ & & & & & & \\
\hline & c) & $\mathrm{C}$ & $\begin{array}{c}6.56 \pm 0.060 \\
(57)\end{array}$ & $\begin{array}{c}255 \pm 1.3 \\
(51)\end{array}$ & $\begin{array}{l}87.8 \pm 0.11 \\
(10)\end{array}$ & $\begin{array}{c}0.322 \pm 0.0018 \\
(24)\end{array}$ & $\begin{array}{c}0.819 \pm 0.0054 \\
(24)\end{array}$ & $\begin{array}{l}8.4 \pm 0.27 \\
(10)\end{array}$ & $\begin{array}{l}21.3 \pm 0.84 \\
(10)\end{array}$ & 26.0 \\
\hline & & $\mathrm{G}$ & $\begin{array}{c}6.45 \pm 0.070 \\
(50)\end{array}$ & $\begin{array}{c}243 * * * \pm 1.7 \\
(48)\end{array}$ & $\begin{array}{l}88.2 \pm 0.06 \\
\quad(10)\end{array}$ & $\begin{array}{c}0.311 * * 0.0034 \\
(25)\end{array}$ & $\begin{array}{c}0.752 * * * \pm 0.0080 \\
(25)\end{array}$ & $\begin{array}{l}8.1 \pm 0.25 \\
(10)\end{array}$ & $\begin{array}{c}19.8 \pm 0.69 \\
(10)\end{array}$ & 26.3 \\
\hline \multirow{2}{*}{\multicolumn{2}{|c|}{ Three-week old }} & $\mathrm{C}$ & $\begin{array}{c}47.24 \pm 1.245 \\
(32)\end{array}$ & $\begin{array}{c}1447 \pm 32.0 \\
(30)\end{array}$ & $\begin{array}{l}80.1 \pm 0.13 \\
\quad(10)\end{array}$ & $\begin{array}{c}0.189 \pm 0.0018 \\
(15)\end{array}$ & $\begin{array}{c}2.735 \pm 0.0447 \\
(15)\end{array}$ & - & - & 一 \\
\hline & & $\mathrm{G}$ & $\begin{array}{c}40.13 * * * \pm 1.309 \\
(27)\end{array}$ & $\begin{array}{c}1339 * * * \pm 15.2 \\
(25)\end{array}$ & $\begin{array}{c}80.4 \pm 0.05 \\
(5)\end{array}$ & $\begin{array}{c}0.195 * \pm 0.0023 \\
(15)\end{array}$ & $\begin{array}{c}2.683 \pm 0.0362 \\
(15)\end{array}$ & - & 一 & - \\
\hline \multirow[t]{4}{*}{ Ten-week old } & $\mathrm{G}$ & & $\begin{array}{c}265.9 \pm 7.94 \\
(11)\end{array}$ & $\begin{array}{c}1824 \pm 29.5 \\
(10)\end{array}$ & - & $\begin{array}{c}0.143 \pm 0.0028 \\
(14)\end{array}$ & $2.570 \pm 0.0418$ & - & - & - \\
\hline & & $\mathrm{F}$ & $\begin{array}{c}188.5 \pm 4.44 \\
(10)\end{array}$ & $\begin{array}{c}1739 \pm 21.5 \\
(10)\end{array}$ & & & & & & \\
\hline & $\mathrm{G}$ & $M$ & $\begin{array}{c}243.6 \pm 12.17 \\
(10)\end{array}$ & $\begin{array}{c}1671 * * \pm 38.2 \\
(10)\end{array}$ & - & $\begin{array}{c}0.144 \pm 0.0046 \\
(12)\end{array}$ & $\begin{array}{c}2.489 \pm 0.0856 \\
(12)\end{array}$ & - & 一 & - \\
\hline & & $\mathrm{F}$ & $\begin{array}{c}184.1 \pm 6.91 \\
(10)\end{array}$ & $\begin{array}{c}1649 * \pm 26.7 \\
(10)\end{array}$ & & & & & & \\
\hline
\end{tabular}

1 Values expressed as mean \pm standard error of the mean. Figures in parentheses indicate the number of observations. Asterisks indicate that the mean value in the galactosemic animals differed significantly from the mean value in the corresponding control animals: $* \mathrm{p}<0.05 ; * * \mathrm{p}<0.01 ; * * * \mathrm{p}<0.001$.

${ }^{2} \mathrm{C}=$ control, $\mathrm{G}=$ galactosemia, $\mathrm{M}=$ Male, $\mathrm{F}=$ Female. 
Suggestive evidence of the reduced cell size in brains of the preterm fetuses was not seen in brains of fetuses examined at term. Furthermore, in the brains of followup groups, cell number was normal, although brains remained smaller in size. Unfortunately, not enough of these brains were available for protein determination, and information concerning cell size is lacking. Further studies will be required to determine what types of cells are involved in these biochemical abnormalities. We have no information indicating to what degree these abnormalities affect the function of the brain or what relation the findings in galactose toxicity in the rat fetus can have to the brain damage associated with congenital galactosemia in the human infant.

It is unlikely that the three-week-old animals of rats fed galactose during lactation had galactose toxicity. Although these offspring were significantly smaller than the controls, there was no galactosemia, nor was galactose-1-phosphate found in brains. Spatz and SEGAL [13] also reported that suckling animals of dams fed a $40 \%$ galactose diet were unusually small and postulated that the dams probably excreted galactose in the milk. We examined several samples of milk from rats fed GD and in one sample, found only $0.15 \%$ of free galactose. In other samples, none was found. By three weeks of age, however, these offspring might have been partly weaned and eating the dams' diet. It is possible that the galactose-fed lactating rats might have produced less milk than the controls, perhaps because of the osmotic diuresis induced by galactose. The young, therefore, might have been smaller because of inadequate food intake. An attempt to measure the volume of milk ingested by the suckling rats was unsuccessful. In a small number of three-week-old fetuses of rats that were fed GD during the second half of pregnancy and $\mathrm{CD}$ at the time of parturition, body weights did not differ significantly from those of controls, although brains were smaller.

Although these experiments on the effect of galactose toxicity in the rat fetus cannot be directly compared with the experience of a human galactosemic fetus exposed to galactose derived from its mother, our findings would support the observations of others that the disease process in congenital galactosemia may begin prenatally and that, when recognized, women who are carriers of the galactosemia gene should be advised to avoid milk products during pregnancy.

\section{Summary}

When pregnant rats were fed a diet containing $40 \%$ galactose, the sugar crossed the placenta and was found in fetal blood, amniotic fluid, and urine. Galactose-1- phosphate was found in high concentrations in the fetal brain.

Fetuses of galactose-fed pregnant rats showed growth retardation, which had disappeared by 10 weeks of age. Brains, however, remained permanently small. Estimations of DNA and protein content in brains of galactosemic fetuses indicated that the brains contained decreased numbers of cells. This finding suggesis that galactose toxicity in the rat fetus interferes with cell replication and, perhaps to some extent, with cell growth in the developing brain. This effect may be partially recoverable since brains of term fetuses were less affected than those of preterm fetuses, and in animals examined at three and ten weeks of age, the total DNA content in the brain had returned to normal.

\section{References and Notes}

1. Bannon, S.L.; Higginbottom, R.M.; MaConNELL, J.M. and KAAN, H.W.: Development of galactose cataract in the albino rat embryo. Arch. Ophthal. 33: 224 (1945).

2. Burton, K.: A study of the conditions and mechanism of the diphenylamine reaction for the colorimetric estimation of desoxyribonucleic acid. Biochem.J. 62: 315 (1956).

3. CHow, B.F. and LEE, G.-J.: Effect of dietary restriction of pregnant rats on body weight gain of the offspring. J. Nutr. 82: 10 (1964).

4. Clay, P.R. and Potter, C.T.: A case of galactosaemia with special reference to mental development. Arch. Dis. Child. 30: 147 (1955).

5. Howard, E.: Effects of corticosterone and food restriction on growth and on DNA, RNA and cholesterol contents of the brain and liver in infant mice. J. Neurochem. 12: 181 (1965).

6. HSIA, D.Y.-Y. and WALKER, F.A.: Variability in the clinical manifestations of galactosemia. $\mathrm{J}$. Pediat. 59: 872 (1961).

7. Hsuen, A.M.; Agustin, C.E. and Chow, B.F.: Growth of young rats after differential manipulation of maternal diet. J. Nutr. 91: 195 (1967).

8. Huggett, A.Sr.G. and Nixon, D.A.: Use of glucose oxidase, peroxidase and o-dianisidine in determination of blood and urinary glucose. Lancet ii: 368 (1957).

9. KING, E.J. and GARner, R.J.: Colorimetric determination of glucose. J.clin. Path. 1: 30 (1947).

10. Schwarz, V.: The value of galactose phosphate determinations in the treatment of galactosaemia. Arch. Dis. Ghild. 35: 428 (1960).

11. Schwarz, V.; Holzel, A. and Komrower, G. M. : Laboratory diagnosis of congenital galactosaemia at birth. Lancet $i$ : 24 (1958). 
12. Segal, S. and Bernstein, H.: Observations on cataract formation in the newborn offspring of rats fed a high-galactose diet. J. Pediat. 62: 363 (1963).

13. Spatz, M. and Segal, S.: Transplacental galactose toxicity in rats. J. Pediat. 67: 438 (1965).

14. Wells, H.J. and Well.s, W.W.: Galactose toxicity and myoinositol metabolism in the developing rat brain. Biochemistry 6: 1168 (1967).

15. Woolf, L.I.: Inherited metabolic disorders: galactosemia. Adv. clin. Chem. 5: 1 (1962).

16. Younoszar, M.K.; Peloso, J. and Haworth, J. G. : Fetal growth retardation in rats exposed to cigarette smoke during pregnancy. Amer.J. Obstet. Gynec. (In press.)

17. Obtained from Nutritional Biochemicals Corporation, Cleveland, Ohio.

18. Supported by a grant from the Medical Research Council of Canada.

19. We would like to thank Professor HarRy Medovy and Dr. Victor GHernick for kindly reviewing our manuscript.

20. Requests for reprints should be addressed to J. C. Haworth, M. D., Children's Hospital, 685 Bannatyne Avenue, Winnipeg 3, Manitoba (Canada). 